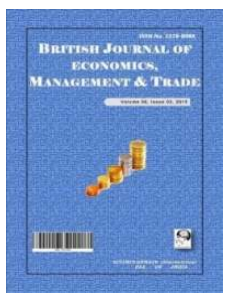

\title{
Determinants of Non-farm Micro and Small Enterprise Participation in Rural Ghana
}

\author{
Sylvester Nsobire Ayambila ${ }^{1 *}$, Isaac Osei-Akoto ${ }^{2}$ and Michael Ayamga ${ }^{1}$ \\ ${ }^{1}$ Faculty of Agribusiness and Communication Sciences, University for Development Studies, \\ P.O.Box TL 1882, Tamale, Ghana. \\ ${ }^{2}$ Institute of Statistical, Social and Economic Research, University of Ghana. P.O.Box LG, 25, Accra,
}

Ghana.

\section{Authors' contributions}

This work was carried out in collaboration between all authors. Authors SNA and IOA managed the statistical analysis of the study. Author SNA wrote the first draft. Author MA did further analysis and wrote the literature review. All authors read and approved the final manuscript.

Article Information

DOI: 10.9734/BJEMT/2017/33814

Editor(s):

(1) Robert Mauritius Kunst, Professor of Economics, University of Vienna, Austria.

Reviewers:

(1) Sule Olatunji Eniola, University of Port Harcourt, Nigeria.

(2) John Walsh, Shinawatra University, Thailand.

Complete Peer review History: http://www.sciencedomain.org/review-history/19367

Original Research Article

Received $30^{\text {th }}$ April 2017

Accepted $31^{\text {st }}$ May 2017

Published $6^{\text {th }}$ June 2017

\begin{abstract}
The non-farm sector is critical for the socio-economic development of Ghana especially the rural poor. This paper analyses the determinants of individual participation in non-farm enterprises and the intensity of participation. The paper used the Economic Growth Centre (EGC)/Institute of Statistical, Social and Economic Research (ISSER) Socio-Economic Survey data collected in 2009. The paper estimated the determinants of participation using a probit model and then estimated the intensity of participation using a truncated regression model. The results indicate that majority of adults engaged in non-farm enterprises in rural Ghana are women (about 73\%). The study found that females tended to participate more in non-farm self-employment and are less likely to participate in non-farm wage employment. The results further showed that individual characteristics such as the gender of the individual, being head of a household, being the spouse of a household head, having formal education, age of the individual, having access to credit, possessing a mobile phone, per capita ownership of land and livestock influenced the participation of individuals in selfand wage employment. Results from truncated regression model for self-employed enterprises showed that having access to mobile phones, owning more livestock and electricity are important in
\end{abstract}


determining the intensity of participation in self-employed enterprises. For wage-employment, being a household head, spouse of household head, having access to mobile phone and owning more livestock increased the number of days working on wage employment. Education is relevant for employment in the non-farm sector especially wage-employment. Government should play a lead role in making formal education accessible to the rural people. Deliberate policies should focus on addressing critical factors such as access to credit, mobile phone, electricity and education which are relevant for increasing participation intensity in rural enterprises.

Keywords: Non-farm; micro and small enterprises; participation; rural Ghana; self-employment; wageemployment.

\section{INTRODUCTION}

Micro and small enterprises (MSEs) are very important and play a critical role in the socioeconomic development of many countries over the world. MSEs have been recognized to have contributed to the socio-economic development in both the industrialized and developing countries [1]. Majority of MSEs are found in the informal sector of developing countries and are the major source of employment and income, especially for the poorest members of society [2]. In Ghana, the non-farm sector plays an important role in providing employment and income for majority of the people especially the rural poor. According to the Ghana Living Standards Survey Round 6 report of 2014, approximately 3.7 million households operate a non-farm enterprise and a higher proportion of household businesses are operated by females $(70.6 \%)$.

Agriculture is the mainstay of the Ghanaian economy employing majority of the people. Even though agriculture is pivotal in the Ghanaian economy, its contribution to Gross Domestic Product (GDP) has been declining slowly over the years. For example, Ghana Statistical Service indicates that the share of the agricultural sector in national output declined from 44 percent in 1990 to 37 percent in 2005 and in 2009, the agricultural sector contribution further declined to $34.1 \%$. Yet, diversification beyond agriculture is often considered a promising pathway out of poverty for impoverished rural economies, and there is a widespread belief that small enterprises may play an important role in especially the early stages of diversifying beyond agriculture $[3,4,5]$.

\subsection{Contribution of MSEs to Socio- economic Development}

MSEs contribute significantly in providing employment for people in Africa such as Kenyan, Nigeria, South Africa and Morocco [6]. Studies in five African countries (Botswana, Kenya, Malawi, Swaziland, and Zimbabwe) found that micro and small enterprises generate nearly twice the level of employment that registered large-scale enterprises and the public sector do [2]. Recent studies suggest that non-farm sources account for 40-45 percent of average rural household income in Sub-Saharan Africa and Latin America and $30-40 \%$ in South Asia with the majority of this coming from local rural sources rather than urban migration $[3,5]$. The share of non-farm income to total household income stood at $70.82 \%$ in Nigeria [7] and non-farm offers the poor a potential escape route from poverty, since they usually require little capital or training to set up and are labour intensive [8].

In Ghana, there are several definitions of MSEs. Some definitions are based on the number of people employed whiles others consider the turnover and value of fixed assets. In Ghana, the most commonly used criterion is the number of employees employed by the enterprise. However, the National Board for Small Scale Industries (NBSSI) considers both fixed assets and number of employees and defines a smallscale enterprise as one with not more than 9 workers, has plant and machinery (excluding land, buildings and vehicles) not exceeding 10 million Cedis (US\$ 9506, using 1994 exchange rate). This study adopted this definition and considers MSEs as enterprises employing not more than 9 workers.

\subsection{Motives for Participation in Non-farm Sector}

Rural farm households in developing countries are expected to focus almost exclusively on farming and undertake little rural non-farm activity, and that policy debate still tends to equate farm income with rural incomes, and rural/urban relations with farm/non-farm relations (Food and Agriculture Organizations, Rome, Unpublished findings). Income diversification 
activities in the rural areas are being recognized as constituting the rural non-farm sector [4]. [3] noted that despite the persistent image of Africa as a continent of "subsistence farmers", non-farm sources may already account for as much as 40 45 percent of average household income and seem to be growing in importance [9].

The motivations of household to enter the nonfarm sector can be categorized into two main factors: "pull" and "push" factors. Households are either "pushed" into or "pulled" out of non-farm activities. [3] recognized that multiple motives prompt households to diversify assets, incomes, and activities. The first set of motives comprise what are traditionally termed "push factors", and these include risk reduction, response to diminishing factor returns, presence of land constraints driven by population pressure and fragmented landholdings, reaction to crisis or liquidity constraints and high transactions, among others. The second set of motives comprise "pull factors", which include the realization of strategic complementarities between activities, such as crop-livestock integration or milling and hog production, specialization according to comparative advantage accorded by superior technologies, skills or endowments among and others.

\subsection{Constraints of MSEs}

Despite the critical role of MSEs in providing a source of livelihood especially for the poor, they are typified by stagnation and high rates of enterprise failure $[10,11]$ and this suggests the need to transform the sector in order to free micro-entrepreneurs from capture by a 'low level poverty trap' [12]. The MSE sector is also associated with poor and/or costly access to credit, problems acquiring new and more productive technologies, low levels of technical and/or managerial skills, high levels of competition among enterprises [2,10,13]. Access to credit is often at the 'top of the list' of problems faced by micro and small enterprises especially among proponents of microcredit [14].

Some amount of studies has been done on small and medium enterprise sector $[15,16,17,18]$. Specific studies have examined the nature and determinants of non-farm work in rural areas of developing countries $[3,19,20]$. In Ghana, there have been a number of studies highlighting the constraints faced by microenterprises and determinants of performance [14]. Studies on individual's participation in non-farm enterprises in Ghana include [20-22] but these did not examine the determinants of intensity of participation, which is usually ignored though potentially important because of its effects on low agriculture productivity [23]. This study in particular included three important variables (total livestock units, credit and mobile phones) which are often missing in previous studies. This study comprehensively examines the factors influencing individuals' participation in rural nonfarm MSEs as well as the intensity of participation.

\section{THEORETICAL BACKGROUND}

The study draws from the theory of the agricultural household by [24] in addressing household participation in the non-farm sector. At the micro level, the model recognizes the dual role of the household as a production and consumption unit. Theoretical approaches in analyzing participation in non-farm employment have their roots in the household model relating to the theory of the household. The theory of the household describes the household as a semicommercialised entity that combines in a single institution, decisions relating to production, consumption, and reproduction over time [24]. In order to analyse individual participation in nonfarm enterprises, this study uses a utility maximization framework under the theory of the household as given by [24]. In the case where there are perfect markets, the household maximizes profit by selecting different sets of income activities based on household endowments (resources) and prices and maximizes utility by selecting different levels of consumption and leisure. However, in the case of market imperfections, production and consumption decisions become non-separable [25]. This implies that households maximise utility, given their resources, the available technology, and (often household-specific) market-access and prices [24]. According to [26], the household approach is justified when both production and consumption decisions are interrelated and when household characteristics play an important role in determining household behavior, as is the case in imperfect markets. The household fundamentally is confronted with the problem of simultaneously dealing with production, consumption and work decisions. [24] specify the structural form of the model as follows:

Max $U\left(c_{a}, c_{m}, c_{l} ; z^{h}\right)$ : Utility function $\mathrm{q}_{\mathrm{a}}, \mathrm{x}, \mathrm{l}, \mathrm{c}_{\mathrm{a}}, \mathrm{c}_{\mathrm{m}}, \mathrm{c}_{\mathrm{i}}$ 
s. t.: $g\left(q_{a}, x, l ; z^{q}\right)=0$ : Production function

$p_{x} x+p_{m} c_{m}=p_{a}\left(q_{a}-c_{a}\right)+w\left(l^{s}-l\right):$ Cash constraint

$\mathrm{C}_{1}+\mathrm{l}^{\mathrm{s}}=\mathrm{E}$ : Time constraint

Where: $z^{\text {h }}$ denotes household characteristics, $p_{a}$ and $p_{m}$ represent prices of commodities $c_{a}$ and $c_{m}$ consumed by the household and $p_{a}$ denotes the market price for $q_{a}$ output produced by the household. $\mathrm{C}_{1}$ and $\mathrm{I}^{\mathrm{s}}$ denote time spent at home and work, respectively, out of a total time endowment $\mathrm{E}$. represents Firm characteristics are represented by $Z^{q}$ and $p_{x}$ is the price of input $x$ that the household employs in production.

\subsection{Theoretical Model}

Based on the theoretical framework discussed in section 2 , the study proceeds to derive a labour supply function from the constrained utility maximization problem according to [24] as follows:

$$
L^{s}=f(p, k, z)
$$

Where:

$$
\begin{aligned}
& \mathrm{L}^{\mathrm{s}}=\text { Labour supply } \\
& \mathrm{P}=\text { Vector of input and output prices } \\
& \mathrm{K}=\text { Vector of capital available to the } \\
& \text { household }
\end{aligned}
$$

$Z=$ Vector of household characteristics

Corral and Reardon [27] explain the variables in the labour supply function in terms of household's incentives and capacities. In explaining the variables in the model, incentives are expressed as the "returns and risks" in the form of prices of inputs and outputs, wages, and production risks, whiles capacities are expressed as the vectors of capital and household characteristics which make it able to respond to the incentives. Capital assets are described here as the level of education, number of cattle owned, and amount of land owned, for example [27]. The potentially higher returns to labour that could be obtained from working off the farm would "pull" or lure households into diversifying. [4] similarly explain that households which are "pulled" into non-farm activities participate as a means of obtaining more income and improving their current living conditions. Factors such as risk to the farm production, and lack of access to credit, for example tend to "push" households into nonagricultural activities and that households that are "pushed" into nonagricultural activities resort to diversification as a safety net. Capacities are regarded as assets at the individual and household level which are vectors of capital including human capital, physical capital, social capital and organizational capital. The various capacities a household possesses affect its ability to take advantage of the incentives.

\section{METHODOLOGY}

\subsection{Modeling the Determinants of Participation and Participation Intensity}

The study employed probit and truncated regression models to determine the factors influencing individual participation and intensity of participation in non-farm MSEs in rural Ghana. Based on previous studies, including [9] and [4], four sets of variables which influence individual participation in non-farm enterprises are identified. First, the individual characteristics, which include education, age, gender, parental and migration history and household member status; the personal assets of individuals. Second, household level characteristics, which include the number of dependents, number of household members, land holdings, and livestock. Third, community level variables which include community social capital, and lastly, location characteristics of the enterprise captured by a dummy variable, which is the ecological zone. The individual decision to participate in the non-farm sector is a function of his/her productive assets (ability, skills, knowledge, motivation, finances, physical status of the household) and the array of opportunities available in the environment in which he/she lives. According to [21], the following sets of factors influence the individual decision to participate in non-farm enterprises in Ghana: the individual characteristics (age of the individual, gender, education, marital status, status as household head, status as spouse of household head; household characteristics (land size, access to electricity, distance to drinking water source; and a location variable. This study followed [21] in specifying the variables, but included three other equally important variables (access to credit, use of mobile phone and total livestock units). [28] found that access to credit is an important determinant of multiple non-farm activities as well as non-farm income in rural Ghana. According to the Rural Poverty Report of 2011, improved communication and information systems, particularly the diffusion of mobile 
phone coverage in rural areas played a role in stimulating the rural non-farm sector. Owning more livestock reduces the number of days worked in non-farm wage employment and livestock ownership is not important for wageemployment (V Sanchez, Michigan State University, USA, Unpublished M. Sc. Thesis).

The study employed a standard probit model in estimating the factors influencing individual participation in non-farm enterprises. The dependent variable is dichotomous in that it takes two modalities, zero and one, depending on whether the individual participates in a nonfarm enterprise or not. Since the dependent variable is not continuous, the application of linear regression models is not appropriate. This means that the use of probit or logit models is more appropriate. Probit model was chosen for its appropriateness in allowing for the estimation of marginal effects and its fitness to the data. The standard probit model is specified as;

$$
\begin{aligned}
& y^{*} i=x_{i}^{\prime} \beta+\mathcal{E}_{i} \\
& y i=1, \text { if } y^{*} i=1 \\
& y i=0, \text { otherwise }
\end{aligned}
$$

Where, $\mathrm{i}=1,2, \ldots, \mathrm{N}$, and $\varepsilon_{i}$ is assumed to be NID $(0, \delta 2)$ and independent of $x_{i}$.

$x_{i}$ is a vector which corresponds to sets of individual, household and community (location) characteristics, $\beta$ is a vector of estimated parameters, and is $\mathcal{E}_{i}$ the error term.

In this case, $y$ is a categorical variable defined as $y=1$, if the individual participates in non-farm activities (either as self-employed or wage earner) as the primary occupation and 0 if the individual participates in agriculture as the main occupation.

To model the factors influencing the intensity of participation, the study used a truncated regression as in the case of the second stage of the Double-hurdle model. The use of truncated regression is to address the bias introduced when using ordinary least squares (OLS) regression on truncated data. The double-hurdle approach allows distinction between the determinants of participation and the level of participation through two separate stages. The truncated regression model was used to determine the intensity of participation or otherwise analyse the determinants of how many days per year an individual allocates to the non-farm enterprise. The model is specified as follows (V Sanchez, Michigan State University, USA, Unpublished M.Sc. Thesis);

$$
L=L^{*} \text { if } L^{*}>0 \text { and } P^{*}>0, \quad L=0 \text { otherwise }
$$

Where: $L^{*}$ is the observed level of participation (number of days worked on non-farm enterprises) in non-farm MSEs, $P^{*}$ is the probability of participation, and $\mathrm{X} 1-\mathrm{X} 3$ correspond to sets of individual, household and community (location) characteristics, respectively. $\beta 1-\beta 3$ are the vectors of estimated parameters and $\mathrm{u}$ is the error term. The individual first decides whether to participate in non-farm enterprise or not, and based on that decision, chooses the number of days to commit to non-farm work. Using a single stage procedure to estimate the factors that influence individual participation in non-farm enterprise and the number of days one would commit to working on non-farm activity could raise the issue of sample selection bias. The study estimated the model using Heckman model. The decision to estimate the two equations separately or together was determined based on the significance of the statistical independence between the two (the decision to participate in non-farm enterprise equation and the number of days one would commit to working on the non-farm enterprises). If the null hypothesis is rejected based on the statistical independence between the two, then a multistage procedure must be used in the estimation.

\subsection{Data and Study Area}

The study was conducted in Ghana and data was obtained from the Economic Growth Centre (EGC)/Institute for Statistical, Social and Economic Research (ISSER) Socio-Economic Survey data (wave one) collected in 2009. The survey was conducted across the 10 regions in Ghana. It covered 5009 households with a total of 18,889 individuals. It is a nationally representative survey from 334 Enumeration Areas (EAs) across the country. Fifteen households were selected from each of the EAs. A two-stage stratified clustered sample design was used for the survey. Stratification was based on the regions of Ghana. The first stage involved 
selecting geographical precincts or clusters from an updated master sampling frame constructed from the 2000 Ghana Population and Housing Census. A total of 334 clusters (census enumeration areas) were selected from the master sampling frame. The clusters were randomly selected from the list of EAs in each region. A complete household listing was conducted in 2009 in all the selected clusters to provide a sampling frame for the second stage selection of households. The second stage of selection involved a simple random sampling of 15 of the listed households from each selected cluster. The primary objective of the second stage of selection was to ensure adequate numbers of completed individual interviews to provide estimates for key indicators with acceptable precision at the regional level. The main field work for the survey covered a 6-month period (November 2009 to April 2010). The strength of this data lies in the geographical spread of the sample. The sampling followed the sampling frame and techniques used by the Ghana Statistical Service.

\subsection{Description of Variables used in the Analysis}

Variables for the study were selected based on theoretical foundation. There are four dependent variables in this study. The first two are dichotomous variables which takes on the value one if the individual participates in non-farm activities (either as self-employed or wage earner) as the primary occupation and 0 corresponding to an individual participating in agriculture as the main occupation. An individual participates in non-farm enterprises if the individual owns at least a non-farm enterprise. Participation in wage employment means the individual earns a wage by working on non-farm enterprises. The second two dependent variables are continuous variables which are used in modeling the intensity of individual participation in non-farm enterprises (either self-employed or wage earner). Intensity of participation refers to the number of days individuals commit to working on non-farm either as owner or wage earner. The study considers a set of independent variables that corresponds to the theoretical frameworks in the labour supply equation as given by [24]. These variables include individual characteristics, household characteristics and community or location variables will motivate the individual to participate in the non-farm enterprise.

\section{RESULTS AND DISCUSSION}

\subsection{Characteristics of Participants and Non-Participants in the Rural Non- farm Sector}

Women dominate the non-farm sector across all the ecological zones. About $73 \%$ of those selfemployed in non-farm enterprises in rural Ghana are females. Non-farm enterprises owners were older, more educated and more married as compared to those in agriculture. They also used more mobile phones and had more access to credit as compared to their colleagues in agriculture. However, those in agriculture had more acreage of land holdings and owned more livestock as compared to those in non-farm. Rural households are engaged in non-farm enterprises for additional source of income to smoothen consumption and reduce the risks associated with farming. The traditional image of farm households in developing countries is to focus almost exclusively on farming and undertake little rural non-farm activity (Food and Agriculture Organizations, Rome, Unpublished findings). There were more female headed households and more households with access to electricity in the non-farm sector as compared to those in agriculture. Agriculture households had larger household size and had to travel more distance for portable drinking water as compared to those in non-farm enterprises. Details of the comparison between participants and nonparticipants are presented in Table 1.

\subsection{Determinants of Participation in Non- farm Enterprises}

The study used a probit model to estimate the factors influencing individual participation. The decision to estimate the models separately using a probit and a truncated regression was based on the fact that the Wald test of independence of equations (Rho) was not significantly different from zero, hence failure to reject the null hypothesis of no difference. The results from the Heckman selection model for self-employment showed that the Rho was 0.02 and the p-value of the chi-square (chi2) was 0.8884 . This implied that the "decision to participate model" and the "intensity of participation model", could be treated as two independent equations and estimated separately. The results from the Heckman selection model for wage-employment showed that the Rho was 0.87 and the $p$-value of the chisquare (chi2) was 0.3510 also indicating that the "decision to participate" and the "intensity of 
participation" could be treated as two independent equations. Results from the regression analysis show the marginal effect on participation given a one unit change or a discrete change in the explanatory variables.

Participation in the non-farm sector is a function of individual, household and locational characteristics. The following individual variables were significant determinants of participation in the non-farm sector. These include the gender of the individual, being head of a household, being the spouse of a household head, having formal education, age of the individual, having access to credit, possessing a mobile phone per capita landing holding and ownership of livestock. Generally, the effects of individual characteristics on the probability of individual participation in non-farm self-employment were consistent with a priori expectations. Except gender, ownership of livestock and being the spouse of the household head, the rest of the variables had the same signs and were significant across wage and selfemployment. The results indicate that females are more likely to participate in non-farm selfemployment. However, females were less likely to participate in non-farm wage employment. These findings are similar to the findings of [27]. [28] in earlier studies, argued that the less participation of women in non-farm wage employment could be due to the many roles played by women. Being the spouse of the household head does not increase the probability of participating in non-farm wage employment but is important for non-farm self-employment. An interesting finding of this study is that owning more livestock decreases one probability of participation in the non-farm wage employment. In this case, one may prefer to raise livestock as supposed to offering labour to someone else (Table 2).

Being a household head increases the probability of participating in non-farm employment. However, in analyzing non-farm income diversification in rural Ghana, [22] found no significant difference between male-headed and female-headed households in non-farm activity participation. The effect of human capital on nonfarm participation was positive and significant. Human capital captured here as having formal education exerted a positive and significant effect on participation. Older people were more likely to participate in non-farm self-employment as compared to younger ones. This may be because older people have accumulated some capital to go into non-farm enterprise. [29] stress the importance of life-cycle aspects arguing that the youngest are often better endowed with human capital (such as health or education) but have not yet accumulated assets (land or cattle). [27] found that the likelihood of undertaking a non-agricultural activity, whether self-employed or not, increases with age. Age was quadratically modeled to determine the marginal rate of return of age on the probability of participation. The results showed that age has a U-shaped effect on participation. Age increases the probability of participation but reaches an apex and then declines.

Having access to credit increases the probability of the individual to participate in non-farm enterprises. It is worth noting that studies in Ghana do not often consider access to credit as an explanatory variable but this study found it relevant to include it. This study found that having access to credit increases the probability of participating in non-farm employment. In a related study [22] found that access to credit is an important determinant of multiple non-farm activities as well as non-farm income. In an attempt to capture the effect of technology on participation in the non-farm, this study included having access to mobile phone. The results indicate that having access to mobile phone increases the probability of participation in both wage and self-employment. This emphasizes the importance of technology in the rural areas. As expected, individuals' having large size of landholding decreases the probability of participating in the non-farm enterprise. [30] indicated that due to the rapidly increasing population in Africa, arable land has come under considerable pressure resulting in many households not being able to live on agriculture alone but engage in non-farm activities. [30] observed that surplus cash generated from nonfarm enterprise directly influences the purchase of agricultural inputs. Some studies have indicated that acreage of land owned seem not to have an impact on non-farm self-employment. For instance, [27] and [24] found that land ownership does not have an impact on non-farm self-employment.

Household access to electricity increases the probability of participating in the non-farm economy. This result corroborates the finding of [31] who found that households are less likely to have a non-farm enterprise if they lack access to electricity and suffer from frequent electricity blackouts. Savannah and Forest zones are less likely to participate in non-farm employment as 
compared to the Coastal zone. The Coastal zone includes the capital city of Ghana (Accra) which contains big industries which pull people into non-farm enterprises. Going by the assertions made earlier, less land ownership means more participation in non-farm work. Residing in a town or populated center makes the options of participation in wage and self-employment more accessible [3].

\subsection{Factors Influencing the Intensity of Participation}

Once the decision has been made to participate in the non-farm sector, then analysis can be made about how many days are committed to working in the non-farm sector. Results from the truncated regression showed that an additional increase in TLU will result in an increase in participation in both wage and self-employment. Individuals who possess mobile phones are likely to increase their participation in the non-farm sector. Households that have access to electricity are likely to work more on their nonfarm enterprises. It is interesting to note that ownership of livestock was not relevant in deciding whether or not to participate in non-farm self-employment but important in determining the number of days committed to non-farm selfemployment once the individual decides to participate in the nom-farm sector. Being a household head and spouse of the household head increases the number of days committed to non-farm wage employment. The household head and the spouse have the responsibility of providing the needs of the households and will work more to be able to get more income for their households. Self-employed individuals worked less days as compared to those working on wage employment. On the average self-employed individuals worked 224 days in a year as compared to 294 days of work by those on wage employment. Results from the truncated regression are presented in Table 3.

The results also indicate that as the individual advances in age, the individual works more on self-employed enterprises, until old age sets in when the individual working days begin to reduce. An additional increase in TLU will result in 0.425 increase in the number of working days on wage employment. This implies that individuals having more livestock will increase the number of days working on the wageemployment. In this study, ownership of livestock was captured as TLU which has become the standard practice in Africa [22,32,33]. Ownership of livestock reduces the probability of participating in non-farm wage employment but is important in determining the number of days committed to non-farm wage employment. This is possible in the sense that most rural households do not practice the intensive system of keeping animals where they are confined and fed from time to time. The animals are allowed to roam freely, and sometimes children are the sole keepers. This means that an adult livestock keeper can still have enough time to engage in wage employment and can even work more. This also indicates that once the individual decides to participate in the wage labour market, the individual is likely to commit days to working.

Having large landholding reduces the number of days one works on self-employment. This is expected because individuals have to devote time for agriculture as well as non-farm enterprises. The more time spent on farming, the less time for non-farm. Individuals who possess mobile phones tend to increase their working days in either self or wage employment. Individuals who had access to credit work more on self-employed enterprises. This is expected because they may be required to pay back the credit including interest, and this implies that they would have to work more in order to make enough profits to be able to pay. However, access to credit is not important for non-farm wage-employment. Households that have access to electricity are more likely to work more days in self- employed enterprises than those not having access to electricity. Enterprises that have electricity are better able to work in the evening as compared to those not having electricity.

Being a household head had the greatest magnitude of effect on the number of days worked in self-employment. Household heads worked 36.78 days more as compared to those who are not. Females worked 27.30 days more as compared to that of males. An additional hectare of land owned will result in 1.624 decrease in the number of days worked in the non-farm activity. Spouse of household variable had the greatest magnitude of effect on the number of days worked on wage-employment. Spouse of household heads worked 60.86 days more as compared to those who are not. Possessing a mobile phone had a significant effect on the number of days worked on wageemployment. People who possess mobile phones worked 39.87 days more as compared to those who do not have mobile phones. 
Table 1. Characteristics of participants and non-participants in the rural non-farm sector

\begin{tabular}{llll}
\hline Variables & Non-farm owners & Farmers & t-statistic \\
\hline Individual characteristics & & & - \\
Gender (\% female) & 72.94 & 51.28 & $5.59^{* * *}$ \\
Individual age & 42.42 & 38.84 & $6.51^{* * *}$ \\
Formal education (\%) & 74.27 & 63.31 & $5.09^{\star * *}$ \\
Individual (\% married) & 60.34 & 51.69 & $-3.27^{\star * *}$ \\
Land holding (hectares) & 2.16 & 2.85 & -1.42 \\
Livestock (TLUs) & 0.67 & 0.89 & $8.96^{\star * *}$ \\
Credit (\% that had access) & 18.53 & 9.25 & $10.40^{\star * *}$ \\
Mobile phones (\% possessing) & 77.68 & 60.71 & - \\
Household characteristics & & & $-5.53^{\star \star *}$ \\
Female headed households (\%) & 44.47 & 17.36 & $6.79^{\star * *}$ \\
Household size & 3.58 & 4.25 & $-1.66^{*}$ \\
Access to electricity (\%) & 42.70 & 31.84 & \\
Distance to drinking water source (Km) & 0.49 & 0.69 & \\
\hline
\end{tabular}

Table 2. Determinants of individual participation in non-farm enterprises: Results estimated using a Probit model

\begin{tabular}{|c|c|c|c|}
\hline Variable & $\begin{array}{l}\text { Non-farm wage and } \\
\text { self-employment }\end{array}$ & $\begin{array}{l}\text { Non-farm self- } \\
\text { employment }\end{array}$ & $\begin{array}{l}\text { Non-farm wage- } \\
\text { employment }\end{array}$ \\
\hline \multicolumn{4}{|l|}{ Individual characteristics } \\
\hline Female & $\begin{array}{l}0.0917^{* * *} \\
(0.0113)\end{array}$ & $\begin{array}{l}0.1262^{* * *} \\
(0.0096)\end{array}$ & $\begin{array}{l}-0.0225^{* * *} \\
(0.0042)\end{array}$ \\
\hline Married & $\begin{array}{l}-0.011 \\
(0.0112)\end{array}$ & $\begin{array}{l}0.0024 \\
(0.0094)\end{array}$ & $\begin{array}{l}-0.0040 \\
(0.0030)\end{array}$ \\
\hline Household head & $\begin{array}{l}0.2504^{\star * *} \\
(0.0207)\end{array}$ & $\begin{array}{l}0.1902^{* * *} \\
(0.0187)\end{array}$ & $\begin{array}{l}0.0367^{\star * *} \\
(0.0091)\end{array}$ \\
\hline Spouse of household head & $\begin{array}{l}0.1154^{\star * \star} \\
(0.0249)\end{array}$ & $\begin{array}{l}0.0865^{\star \star \star} \\
(0.0212)\end{array}$ & $\begin{array}{l}0.0111 \\
(0.0092)\end{array}$ \\
\hline Education & $\begin{array}{l}0.0398^{\star * \star} \\
(0.0087)\end{array}$ & $\begin{array}{l}0.0182^{\star \star} \\
(0.0073)\end{array}$ & $\begin{array}{l}0.0150^{\star * \star *} \\
(0.0027)\end{array}$ \\
\hline Age & $\begin{array}{l}0.0157^{\star * \star} \\
(0.0018)\end{array}$ & $\begin{array}{l}0.0110^{* * *} \\
(0.0014)\end{array}$ & $\begin{array}{l}0.0027^{* * \star} \\
(0.0006)\end{array}$ \\
\hline Age squared/100 & $\begin{array}{l}-0.0178^{* * *} \\
(0.0019)\end{array}$ & $\begin{array}{l}-0.0123^{* * *} \\
(0.0015)\end{array}$ & $\begin{array}{l}-0.0032^{* * *} \\
(0.0006)\end{array}$ \\
\hline Credit & $\begin{array}{l}0.0511^{* * *} \\
(0.0145)\end{array}$ & $\begin{array}{l}0.0311^{* *} \\
(0.0119)\end{array}$ & $\begin{array}{l}0.0311^{\star \star} \\
(0.0119)\end{array}$ \\
\hline Mobile phone & $\begin{array}{l}0.0720^{* * *} \\
(0.0084)\end{array}$ & $\begin{array}{l}0.0473^{\star * *} \\
(0.0069)\end{array}$ & $\begin{array}{l}0.0473^{\star * *} \\
(0.0069)\end{array}$ \\
\hline TLUs & $\begin{array}{l}-0.0011 \\
(0.0011)\end{array}$ & $\begin{array}{l}-0.0000 \\
(0.0007)\end{array}$ & $\begin{array}{l}-0.0039^{*} \\
(0.0022)\end{array}$ \\
\hline Landholding per capita & $\begin{array}{l}-0.0125^{\star * *} \\
(0.0031)\end{array}$ & $\begin{array}{l}-0.0046^{\star *} \\
(0.0021)\end{array}$ & $\begin{array}{l}-0.0031^{\star * \star} \\
(0.0009)\end{array}$ \\
\hline \multicolumn{4}{|l|}{ Household characteristics } \\
\hline Electricity & $\begin{array}{l}0.0506^{* * *} \\
(0.0092)\end{array}$ & $\begin{array}{l}0.0200^{* *} \\
(0.0075)\end{array}$ & $\begin{array}{l}0.0151^{* * *} \\
(0.0032)\end{array}$ \\
\hline Distance to drinking water & $\begin{array}{l}-0.0046 \\
(0.0037)\end{array}$ & $\begin{array}{l}-0.0029 \\
(0.0027)\end{array}$ & $\begin{array}{l}-0.0011 \\
(0.0014)\end{array}$ \\
\hline \multicolumn{4}{|c|}{ Location/zone characteristics (reference: Coastal) } \\
\hline Savannah zone & $\begin{array}{l}-0.0614^{* * *} \\
(0.0122)\end{array}$ & $\begin{array}{l}-0.0370^{* * *} \\
(0.0101)\end{array}$ & $\begin{array}{l}-0.0084^{* *} \\
(0.0037)\end{array}$ \\
\hline Forest zone & $\begin{array}{l}-0.0572^{* * *} \\
(0.0112)\end{array}$ & $\begin{array}{l}-0.0360^{* * *} \\
(0.0092)\end{array}$ & $\begin{array}{l}-0.0056^{*} \\
(0.0031)\end{array}$ \\
\hline Log pseudolikelihood & -2444.2215 & -2131.3421 & -895.252 \\
\hline Wald $x^{2}(15)$ & 703.22 & 508.46 & 389.03 \\
\hline Prob $>x^{2}$ & 0.0000 & 0.0000 & 0.0000 \\
\hline Pseudo $\mathrm{R}^{2}$ & 0.1917 & 0.1744 & 0.2254 \\
\hline Observations & 6530 & 6530 & 6530 \\
\hline
\end{tabular}


Table 3. Determinants of level of individual participation in non-farm enterprise: Results estimated using a truncated regression on days worked per year

\begin{tabular}{|c|c|c|}
\hline Variable & Non-farm self-employment & Non-farm wage-employment \\
\hline \multicolumn{3}{|l|}{ Individual characteristics } \\
\hline Female & $\begin{array}{l}-13.0006 \\
(13.0922)\end{array}$ & $\begin{array}{l}-27.5333 \\
(17.0851)\end{array}$ \\
\hline Married & $\begin{array}{l}-9.9525 \\
(12.1203)\end{array}$ & $\begin{array}{l}-3.4063 \\
(11.4369)\end{array}$ \\
\hline Household head & $\begin{array}{l}14.1806 \\
(26.8515)\end{array}$ & $\begin{array}{l}50.1511^{*} \\
(26.9278)\end{array}$ \\
\hline Spouse of household head & $\begin{array}{l}17.8378 \\
(27.9578)\end{array}$ & $\begin{array}{l}63.8379^{*} \\
(33.2687)\end{array}$ \\
\hline Education & $\begin{array}{l}-5.6236 \\
(11.5678)\end{array}$ & $\begin{array}{l}3.0093 \\
(16.6872)\end{array}$ \\
\hline Age & $\begin{array}{l}0.1439 \\
(1.9332)\end{array}$ & $\begin{array}{l}0.6586 \\
(2.5818)\end{array}$ \\
\hline Age squared & $\begin{array}{l}-0.1652 \\
(2.0042)\end{array}$ & $\begin{array}{l}-0.0004 \\
(0.0283)\end{array}$ \\
\hline Credit & $\begin{array}{l}12.7569 \\
(11.4711)\end{array}$ & $\begin{array}{l}-8.9427 \\
(12.2836)\end{array}$ \\
\hline Mobile phone & $\begin{array}{l}33.3210^{* *} \\
(12.7417)\end{array}$ & $\begin{array}{l}41.2243^{* *} \\
(16.8971)\end{array}$ \\
\hline TLUs & $\begin{array}{l}8.9464^{* *} \\
(3.5118)\end{array}$ & $\begin{array}{l}0.4299^{\star * *} \\
(0.0867)\end{array}$ \\
\hline Landholding & $\begin{array}{l}-2.9427 \\
(2.3801)\end{array}$ & $\begin{array}{l}0.9629 \\
(1.8713)\end{array}$ \\
\hline \multicolumn{3}{|l|}{ Household characteristics } \\
\hline Electricity & $\begin{array}{l}39.9217^{\star * *} \\
(9.3930)\end{array}$ & $\begin{array}{l}13.5106 \\
(10.4043)\end{array}$ \\
\hline Distance to drinking water & $\begin{array}{l}3.5634 \\
(2.9322)\end{array}$ & $\begin{array}{l}1.9298 \\
(2.0592)\end{array}$ \\
\hline \multicolumn{3}{|c|}{ Zone characteristics (Reference: Coastal) } \\
\hline Savannah zone & $\begin{array}{l}-3.5934 \\
(13.3143)\end{array}$ & $\begin{array}{l}-1.4282 \\
(7.1341)\end{array}$ \\
\hline Forest zone & $\begin{array}{l}5.7314 \\
(11.5450)\end{array}$ & $\begin{array}{l}12.7988 \\
(12.2268)\end{array}$ \\
\hline Constant & $\begin{array}{l}167.3013^{\star * *} \\
(49.4348)\end{array}$ & $\begin{array}{l}161.9937^{* *} \\
(60.2689)\end{array}$ \\
\hline Log pseudolikelihood & -4880.013 & -2417.690 \\
\hline Wald $x^{2}(15)$ & 43.21 & 85.24 \\
\hline Prob $>x^{2}$ & 0.000 & 0.000 \\
\hline
\end{tabular}

\section{CONCLUSIONS}

The probit regression model showed that individual characteristics such as the gender of the individual, being head of a household, being the spouse of a household head, having formal education, age of the individual, having access to credit, possessing a mobile phone, per capita landing holding and ownership of livestock influenced the participation of individuals in selfand wage-employment. However, females are more likely to participate in non-farm selfemployment and less likely to participate in wage-employment. In addition, individuals who owned less livestock were more likely to engage in non-farm wage-employment. Individuals with more landholding are less likely to participate in non-farm self or wage employment. This finding supports the argument in the literature that individuals may set up non-farm enterprises as additional source of income and as a substitute for agriculture for those who do not own. For wage-employment, being a household head, spouse of household head, having access to mobile phone and owning more livestock increased the number of days working on wageemployment. The study showed that being a female increases the probability of participation in self-employment. Contrary, being a female, decreases the probability of participating in wage-employment. Being a household head increases the probability of participation in self- 
employment and in wage-employment. The findings suggest that, there may not be significant barriers to entry into self-employment and the finding that females are less likely to engage in wage-employment may suggest there are significant barriers to entry. [22] found that education was the single most important factor contributing to inequality-increasing of non-farm income in rural Ghana. Thus emphasizing the essence of education to working in the non-farm sector especially wage-employment. Policies should gear towards reducing constraints to entry in the non-farm sector, particularly targeting wage-employment.

This study contributes to the existing knowledge on participation in the non-farm sector and in particular, intensity of participation which is virtually lacking in the Ghanaian context. The study also included three important variables (access to credit, mobile phone and ownership of livestock) which are often missing in previous studies of participation in the nonfarm sector in Ghana. Having access to mobile phones, access to electricity and owning more livestock increased the number of days committed to working on non-farm selfemployment.

Having formal education increases the probability of participation in non-farm self-and wageemployment. Government should play a lead role in making formal education accessible to the rural people. It should encourage female education, since females were less educated as compared to males. Efforts targeting to reduce rural poverty requires strategic investments in rural electrification projects. Deliberate policies should focus on addressing critical factors such as access to credit, mobile phone, electricity and schooling which are relevant for increasing the number of days worked in rural enterprises.

\section{LIMITATION}

Since the data was not collected by the authors, it was difficult to explain some of the reasons behind the figures. Lack of qualitative information to explain some of the context.

\section{ACKNOWLEDGEMENTS}

We are grateful to the Economic Growth Centre (EGC) and the Institute of Statistical Social and Economic Research (ISSER) for providing data for the study.

\section{COMPETING INTERESTS}

Authors have declared that no competing interests exist.

\section{REFERENCES}

1. Nichter S, Goldmark L. Small firm growth in developing countries. World Development. 2009;37(9):1453-1464.

2. Mead DC, Liedholm C. The dynamics of micro and small enterprises in developing countries. World Development. 1998;26 (1):61-74.

3. Barrett CB, Reardon T, Webb P. Non-farm income diversification and household livelihood strategies in rural Africa: Concepts, dynamics and policy implications. Food Policy. 2001;26:315331.

4. Lanjouw J, Lanjouw P. The rural nonfarm sector: Issues and evidence from developing countries. Agricultural Economics. 2001;26(1):1-23.

5. Reardon $T$, Stamoulis $A$, Lanjuow $P$, Balisacan ME. Effects of non-farm employment on rural income inequality in developing Countries: An investment perspective. Journal of Agriculture Economics. 2000;51(2):266-288.

6. Masakure $\mathrm{O}$, Henson S, Cranfield J. Performance of microenterprises in Ghana: A resource-based view. Small Business and Enterprise Development. 2009;16(3): 466-484.

7. Onya SC, Okezie CA, Ejiba V. Determinants of Participation in Non-farm Employment among Rural Farmers in Ebonyi State, Nigeria. Journal of Scientific Research \& Reports. 2016;11(6):1-11.

8. Owusu V, Abdulai A, Abdul-Rahman S. Non-farm work and food security among farm households in Northern Ghana. Food Policy. 2011;36(2):108-118.

9. Reardon T. Using evidence of household income diversification to inform study of the rural non-farm labor market in Africa. World Development. 1997;25(5):735-748.

10. Daniels L, Mead DC. The contribution of small enterprises to household and national income in Kenya. Economic Development and Cultural Change. 1998; 47(1):45-71.

11. Hung MC, Benzing C, McGee C. Ghanaian and Kenyan Entrepreneurs: A comparative analysis of their motivations, success characteristics and problems. Journal of 
Developmental Entrepreneurship. 2007; 12(3):295-322.

12. McKenzie DJ, Woodruff C. Do entry costs provide an empirical basis for poverty traps? Evidence from Mexican microenterprises. Economic Development and Cultural Change. 2006;55(1):3-42.

13. Livingstone I. A reassessment of Kenya's rural and urban informal sector. World Development. 1991;19(6):651-670.

14. Aryeetey E, Hettige H, Nissanke M, Steel WF. Financial market fragmentation and reforms in Ghana, Malawi, Nigeria, and Tanzania. World Bank Economic Review. 1997;11(2):195-218.

15. Sleuwaegen L, Goedhuys M. Growth of firms in developing countries: Evidence from Cote D'lvoire. Journal of Development Economics. 2002;68:117135.

16. Soderbom M, Teal F. Size and efficiency in African manufacturing firms: Evidence from firm-level panel data. Journal of Development Economics. 2004;73:369394.

17. Aworemi JR, Abdul-Azeez IA, Opoola NA. Impact of socio-economic factors on the performance of small-scale enterprises in Osun State, Nigeria. International Business Research. 2010;3(2):92-99.

18. Mahmoud MA. Market orientation and business performance among SMEs in Ghana. International Business Research. 2011;4(1):241-251.

19. Abdulai A, CroleRees A. Determinants of income diversification amongst rural households in Southern Mali. Food Policy. 2001;26:437-452.

20. Canagarajah S, Newman C, Bhattanmishra R. Non-farm income, gender, and inequality: Evidence from rural Ghana and Uganda. Food Policy. 2001; 26(4):405-420.

21. Ackah C. Non-farm employment and incomes in rural Ghana. Journal of International Development. 2013;25(3): 325-339.

22. Glick P, Sahn DE. Gender and education impacts on employment and earnings in
West Africa: Evidence from Guinea. Economic Development and Cultural Change. 1997;45(4):793-823.

23. Matshe I, Young T. Off-farm labour allocation decisions in small-scale rural households in Zimbabwe. Agricultural Economics. 2004;30(3):175-186.

24. Sadoulet E, de Janvry A. Quantitative development policy analysis. Baltimore MD: Johns Hopkins University Press;1995.

25. Taylor E, Adelman I. Agricultural household models: Genesis, evolution, and extensions. Review of Economics of the Household. 2003;1(1):33-58.

26. Caillavet $F$, Guyomard H, Lifran R, editors. Agricultural household modelling and family economics. Amsterdam: Elsevier Science; 1994.

27. Corral L, Reardon T. Rural nonfarm incomes in Nicaragua. World Development. 2001;29(3):427-442.

28. Senadza B. Non-farm income diversification in rural Ghana: Patterns and determinants. African Development Review. 2012;24(3):233-244.

29. Bigsten A, Kayizzi-Mugerwa S. Rural sector responses to economic crisis in Uganda. Journal of International Development. 1995;7(2):181-209.

30. Oseni G, Winters P. Rural nonfarm activities and agricultural crop production in Nigeria. Agricultural Economics. 2009; 40(2):198-201.

31. Gibson $O$. The effect of infrastructure access and quality on non-farm enterprises in Rural Indonesia. World Development. 2010;38(5):717-726.

32. Al-Hassan R, Famiyeh JA, de Jager A. Farm household strategies for food security in Northern Ghana: A comparative analysis of high and low population farming systems. In: Asenso-Okyere WK, Benneh G, Tims, W, editors. Sustainable Food Security in West Africa. Boston MA: Kluwer Academic; 1997.

33. Ramakrishna G, Demeke A. An empirical analysis of food insecurity in Ethiopia: The case of North Wello. Africa Development. 2002;27(1):127-143.

(c) 2017 Ayambila et al.; This is an Open Access article distributed under the terms of the Creative Commons Attribution License (http://creativecommons.org/licenses/by/4.0), which permits unrestricted use, distribution, and reproduction in any medium, provided the original work is properly cited.

Peer-review history:

The peer review history for this paper can be accessed here: http://sciencedomain.org/review-history/19367 